\title{
AS POLÍTICAS QUEER DE MIGRAÇÃO: REFLEXÕES SOBRE "ILEGALIDADE" E INCORRIGIBILIDADE
}

\author{
Nicholas De Genova ${ }^{1}$
}

\begin{abstract}
A expressão ${ }^{2}$ de maior ressonância das mobilizações, verdadeiramente sem precedentes, de imigrantes nos Estados Unidos em 2006 foi uma proclamação em massa de rebeldia coletiva: iAquí estamos y no nos vamos! Este mesmo slogan foi frequentemente acompanhado por uma afirmação ainda mais vigorosa, incorrigível: iY si nos sacan, nos regresamos! É impressionante e, como este ensaio sustenta, não apenas provocativo, mas até genuinamente produtivo notar a afinidade entre a articulação fundamental dessa política radicalmente aberta de presença migrante com as políticas abjetas semelhantes e profundamente desestabilizadoras da presença queer. De maneira muito semelhante ao slogan: "Nós estamos aqui, nós somos queer, acostume-se com isso!", a proclamação dinâmica dessas frases no contexto das mobilizações de massa de migrantes comprova um espírito irredutível de irreverência e desafeição em relação ao poder do Estado. Ambos os gestos, sem restrições e sem remorsos, não atestam somente sua irreversível presença, mas sustentam também o desafio intransigente de sua intrínseca incorrigibilidade ${ }^{3}$.
\end{abstract}

Palavras-chave: migração irregular, guerra contra o terrorismo, deportação/ deportabilidade, políticas de mobilidade, políticas de presença.

1 Departamento de Geografia do King's College de Londres. Londres, Inglaterra.

2 A REMHU publica este artigo, por sugestão e autorização do Autor, com tradução própria. O original foi publicado com o título "The Queer Politics of Migration: Reflections on 'Illegality' and Incorrigibility" na revista Studies in Social Justice, Volume 4, Issue 2, 101-126, 2010. Diferentemente das normas editoriais da REMHU, este artigo é publicado com as notas de rodapé conforme o texto se apresenta na primeira publicação, em inglês, mantendo o sistema autor-data, os itálicos do texto original, assim como o formato das referências bibliográficas.

3 Sou verdadeiramente grato a Tanya Basok por me convidar a contribuir para esta edição da SSJ; sem a sua iniciativa editorial, eu, talvez, não teria tido a oportunidade de desenvolver os pensamentos apresentados neste ensaio. Esboços anteriores foram apresentados ao público acadêmico e a ativistas em Roma, Bolonha e Amsterdam. Devo uma nota de agradecimento também para Nina Trige Andersen, Sébastien Chauvin, Ayça Çubukçu, Paul Mepschen, Sandro Mezzadra, Enrica Rigo, Maria Vittoria Tessitore e Bertil Videt pelos seus vários papéis nessas ocasiões. Recebi muitas críticas bem pertinentes de Ayça Çubukçu, Ramón Gutiérrez, Engin Isin, Naledi Nomalanga Mkhize e Nathalie Peutz, que têm desafiado e enriquecido meu pensamento neste ensaio. Também tenho uma nota de agradecimento aos vários colegas e alunos cuja teoria e prática têm me ajudado, de várias formas ao longo dos anos, a chegar às ideias presentes, especialmente: Alejandro Amezcua, Rutvica Andrijasevic, Adriana Garriga-López, Amanda Gilliam, Marcial Godoy, María Lugones, Sofian Merabet, Sandro Mezzadra, Dimitris Papadopoulos, Joshua Price, e Marie Varghese. 
iAquí Estamos, y No Nos Vamos!

- Slogan da mobilização migrante

Nós estamos aqui, nós somos queer, acostume-se com isso!

- Slogan da mobilização queer

"Esta é uma narrativa antiassimilacionista sobre um movimento antiassimilacionista"

- Lauren Berlant e Elizabeth Freeman, "Queer Nationality" (1992, p. 154)

A expressão de maior ressonância - e, para mim, com certeza, a mais radiante - das mobilizações, verdadeiramente sem precedentes, de imigrantes nos Estados Unidos em 2006 foi uma proclamação em massa de rebeldia coletiva: iAquí estamos, y no nos vamos! Este mesmo slogan foi frequentemente acompanhado por uma afirmação ainda mais vigorosa, incorrigível: iY si nos sacan, nos regresamos! O refrão, em si, não era novo; foi o produto de uma potente e constante articulação de lutas de migrantes nos Estados Unidos no decorrer de muitos anos ${ }^{4}$. Mas a repetição veemente dessas frases no contexto das mobilizações de massa revigorou o espírito irredutível de irreverência e desafeição em relação ao poder estatal.

Énotório, nãosendo necessário insistir naargumentação, queas mobilizações de 2006 foram instigadas pela aprovação na Câmara dos Representantes dos EUA da detestável Lei de Proteção das Fronteiras, Antiterrorismo e Controle da Imigração Ilegal (HR4437, aprovada em 16 de dezembro de 2005, também conhecida como o Projeto de Lei Sensenbrenner) que, sem dúvida, foi a legislação migratória mais punitiva na história dos EUA.

Esta tentativa de emboscada legislativa particularmente repressiva juntou explicitamente sua proposta de criminalização da "imigração ilegal" com a metafísica dominante do antiterrorismo e sinalizou, abertamente, sua própria condição de possibilidade sob a égide do que tenho chamado de Estado de Segurança Interna (De Genova, 2007a). Em resposta, milhões de migrantes (tanto "ilegais" quanto "legais"), junto com seus filhos, muitos deles cidadãos norteamericanos, reuniram-se e marcharam em protestos em todo os Estados Unidos, chacoalhando várias vezes o país ao longo de um período de quase dois meses (Baker-Cristales, 2009; Bloemraad \& Trost, 2008; De Genova, 2009; Gonzales, 2009; Heiskanen, 2009; Hincapié, 2009; Johnson e Hing, 2007; Pulido, 2007; Robinson, 2006; Lazos Vargas, 2007; \& Voss Bloemraad, n.d.)5. Uma rebelião

4 Sobre protestos de migrantes na década de 1990, ver Coutin (2000, p. 42; cf. 1999; 2003); Crawford (2007); Lipsitz (2006, p. 312). De fato, Raúl Villa (2000) postula que a sensibilidade claramente espacial desta declaração é "barriological" e reinscreve a sua genealogia dentro da história das formações socioculturais Chicanas. Sem referir-se à frase em si, Villa remonta essa sensibilidade ao Los Angeles Barrio Writers Workshop/Los Angeles Latino Writers' Association no fim da década de 1970 e início de 1980 (p. 107-109).

5 Uma estimativa das manifestações documentadas, com base nos relatórios mais conservadores da mídia oficial, chega a uma participação total que varia de 3,5 milhões para mais de 5 milhões em todos os eventos conhecidos na primavera de 2006. Veja o banco de dados disponível em: <www. 
totalmente imprevista ${ }^{6}$ de pessoas pertencentes, sobretudo, à classe trabalhadora (ou trabalhadores pobres), racialmente subordinadas (não-brancos) e, muitas vezes, legalmente vulneráveis (deportáveis), criou uma crise política para o Estado norte-americano - desestabilizando as complacências antiterroristas e o senso comum nativista do discurso dominante, desorientando e paralisando o debate oficial sobre a "reforma de imigração" da classe política e, finalmente, reorientando a proposta de Lei. Efetivamente, a este respeito, não é preciso entrar no detalhe se essas mobilizações constituem realmente um "movimento" ou se são apenas uma espécie de "evento" que pareceu evaporar tão rapidamente como apareceu: ao contrário de muitos outros movimentos sociais ou políticos mais antigos e consolidados, esse realmente exerceu tanta força que alcançou muito rapidamente o seu primeiro e definitivo objetivo - de forma breve, derrotou a ameaçadora e abominável lei. O poder soberano do Estado nacional e sua política asfixiante de cidadania foram abruptamente colapsados pelo abjeto protagonismo de habitantes transnacionais do capital global (De Genova, 2009; cf. 2010b).

Este ensaio não se propõe a afirmar que as políticas das mobilizações de 2006 nos Estados Unidos foram, de alguma forma, uma "pura" ou "primitiva" explosão de energias contra-hegemônicas e uma crítica radical - como se não fossem contaminadas pelas compulsões assimilacionistas hegemônicas e pelos conceitos nacionalistas do discurso dominante sobre imigração nos EUA (De Genova, 2005, pp. 56-94). Contrariamente, a proposta deste ensaio é justamente aprofundar e esclarecer a crítica desses dilemas epistemológicos e metodológicos, bem como dos enigmas políticos. Também não é a pretensão deste ensaio sobrepor qualquer aparência de coerência dogmática pré-fabricada sobre um movimento de massas que foi claramente heterogêneo e repleto de contradições internas. Tais esforços parecem ser fantasiosos ao extremo, romantizando ingenuamente um campo sóciopolítico que merece um exame mais sóbrio e exigente. Mas o extraordinário alcance de reconhecimento do refrão "aquí estamos", assim como a elevada cristalização de uma persistente e urgente sensibilidade coletiva dos protestos, são inegáveis e significativos (cf., por exemplo, Hincapié, 2009; Robinson, 2006). Na medida em que este slogan, mais do que qualquer outro, teve uma profunda ressonância de grande alcance para os migrantes engajados nesta luta, é absolutamente necessário que nós tenhamos em consideração seu conteúdo enquanto expressão orgânica de um dos impulsos - não necessariamente o único - que animaram as mobilizações e deram energia a seu imaginário político.

Se o movimento teve uma tarefa imediata, clara e concisa (a derrota do HR4437), que foi atingida com uma rapidez impressionante, ele também se articulou

wilsoncenter.org/migrantparticipation>.

6 Apesar da genuína solidez organizativa que contribuiu em todos os lugares para o sucesso do movimento (ver, por exemplo, Gonzales, 2009; Voss \& Bloemraad, n.d.), não deixa de ser inegável que as lutas de 2006 alcançaram sua notável força e seus objetivos rapidamente, com a disseminação imediata de uma aguda consciência dos desdobramentos particularmente ofensivos e ameaçadores da nova legislação. 
em uma variedade de termos mais amplos. Nós estamos aqui e não vamos sair! Assim ressoou a mensagem mais elementar do movimento, a principal expressão de sua prerrogativa política. Cabe ressaltar que esta não era uma "demanda": não cobrou legisladores, não pleiteou algum caso jurídico, não requisitou políticos, não recorreu a autoridades policiais. Em vez disso, este refrão recorrente, afirmado vigorosamente, asseverou o tema da presença - a presença profunda e inextricável dos migrantes, e especialmente a dos não documentados - dentro da formação social norte-americana e dentro do espaço do Estado. Na verdade, a questão da "presença ilegal" dos migrantes (precisamente o alvo de criminalização pela proposta de Lei) apontou para um ponto de conflito crucial para ambos os lados na luta política sobre a imigração nos Estados Unidos. Como veremos mais adiante, esta afirmação da presença dos migrantes como um fato "político", formulada em relação ao Estado, era, ao mesmo tempo e inseparavelmente, um fato "econômico" com base na presença inextricável do poder (laboral) dos migrantes, enquanto trabalhadores. Para muitos dos imigrantes que se engajaram no assim chamado "debate sobre a imigração" através da participação nessas mobilizações de massa, sua presença "não autorizada", em última análise, figurou como o definitivo fato "objetivo", social e político: sua afirmação audaciosa - sua reinscrição como pura insubordinação - parecia significar um fim em si mesmo (De Genova, 2009).

Além disso, o caráter ousado e destemido desta postura só foi superado por sua inflexível intransigência e incorrigibilidade: foi um gesto profundamente antiassimilacionista. Nós estamos aqui, eles proclamaram e, por implicância, insistiram: Nós somos quem somos e o que somos. Os milhões de pessoas que, literalmente, colocaram seus deportáveis corpos na linha de frente desta luta - pelo menos quando gritavam este slogan - não estavam implorando a ninguém por seus supostos "direitos" humanos e civis, não estavam pedindo a qualquer autoridade permissão ou perdão e não buscavam a aprovação ou aceitação de ninguém . Além disso, através da arrogante promessa de que, mesmo se fossem deportados, eles certamente retornariam, esses migrantes provocavam também os presunçosos e os moralistas superintendentes do regime de deportação: Não há nada que você possa fazer sobre isso, seu poder repressivo não é nada em comparação ao poder de nossa vitalidade e nossa vontade indomável de perseverar e vencer.

\footnotetext{
Em um contexto relacionado, mas divergente, Susan Coutin (1999) também constatou a importância para os migrantes não documentados do tema da presença que está em jogo neste slogan (p. 63). Coutin (2000) discute este slogan, com perspicácia, no caso particular dos salvadorenhos (não documentados) solicitantes de asilo que lutam para o reconhecimento legal, comparando-o à passagem memorável do Dr. Seuss Horton no clássico infantil Hears a Who, onde "a fim de evitar a destruição de seu mundo por aqueles que duvidavam de sua existência, todos os Whos em Whoville tinham que gritar: 'Estamos aqui! Estamos aqui!'” (p. 42). Nestas circunstâncias em que os salvadorenhos estavam de fato em busca de reparação legal do Estado, Coutin (2003) chega a sugerir que "a afirmação 'aquí estamos' começa a parecer mais importante do que a desafiante 'y no nos vamos'" (p. 186). Em contraste com o que estou descrevendo como o desafio vigoroso das mobilizações de massa 2006, Coutin (1999) explica: "Ao afirmar sua presença, estes imigrantes não autorizados reivindicam tanto a legitimidade quanto a adesão formal na política" (p. 60).
} 
É impressionante e, como defendo neste ensaio, não meramente provocativo, mas genuinamente produtivo, notar a afinidade entre a articulação fundamental dessas políticas radicalmente abertas de presença migrante com as semelhantes políticas abjetas e profundamente desestabilizadoras da presença queer. ${ }^{8}$ Os dois slogans, justapostos na epígrafe deste ensaio, de fato, fazem exatamente a mesma declaração: Nós estamos aqui, nós nos recusamos de sair e não podemos ser removidos. De uma maneira extremamente semelhante ao slogan "Nós estamos aqui, nós somos Queer, se acostumem com isso" - originariamente associado aos militantes da Queer Nation ${ }^{9}$ (especialmente os homens gays com AIDS e seus aliados) - o refrão "aquí estamos" das mobilizações migrantes "encena a mudança da silenciosa ausência para a presença eloquente, da insignificância para a coletividade, de uma política de incorporação para uma política de espaço, cujo poder emana da ambiguidade do 'aqui'" (Berlant \& Freeman, 1992, p. 156). Ambos os gestos, sem restrições e sem remorsos, afirmam não só sua presença irreversível, mas sustentam também o irredutível desafio de sua intrínseca incorrigibilidade.

\section{Abjeção Migrante / Política Queer}

Enquanto objetos de um crescente e insólito clima de securitização, os migrantes têm sido cada vez mais retratados, ao longo dos últimos anos, como possuindo um protagonismo discutível que, na melhor das hipóteses, é desagradável, para não dizer francamente perigoso (De Genova, 2007a). A abjeção é um quadro interpretativo especialmente apto para compreender a complexidade da condição do migrante precisamente porque os migrantes estão já/desde sempre dentro do espaço do Estado e nunca podem ser totalmente expelidos. Julia Kristeva descreveu de forma significativa a especificidade do

8 Não é proposição deste ensaio discutir as interseções de migração, identidades queer e política de imigração. Há, evidentemente, um campo forte ecrescente de excelentes estudosque fazem precisamente isso; ver, por exemplo, Cantú (2009); Luibheid (2002; 2008); Luibheid e Cantú, eds. (2005); Puar (2007); Puar e Rai (2002); Somerville (2005). Para outra tentativa de trazer as ideias das abordagens de gênero e sexualidade para o tema da migração, de modo mais geral, ver Andrijasevic (2009). Desconhecida para mim na primeira vez que escrevi este ensaio, a campanha ativista de estudantes não documentados, geralmente criados e educados nos Estados Unidos, como as crianças filhas de migrantes em situação irregular que defendiam sua própria "legalização" através do DREAM Act (Development, Relief and Education for Alien Minors Act), inaugurada em 10 março de 2010 como "National Coming Out Day", iniciou uma série de "National Coming Out Days" em todo os Estados Unidos em que tais sujeitos declararam-se abertamente "em situação irregular, mas sem medo". O tema LGBT/queer foi revelador juntamente com o discurso da imigração de "sair das sombras" e em um site militante foi acompanhado com uma citação do ícone da libertação gay, Harvey Milk: www.dreamactivist.org/blog/2010/03/05/ comeout/; cf. também: www.nytimes.com/2010/03/12/us/politics/12immig.html?th\&emc=th; quanto a outros sites ativitas sobre a campanha mais ampla: www.dreamact.com; www.dreamactivist.org; e www. thedreamiscoming.com (sites acessados em 30/06/2010).

9 Para uma análise crítica das figuras equívocas e controversas de "nação" e "nacionalidade" queer, veja Berlant e Freeman (1992) e Bérubé e Escoffier (1991). Para uma discussão sobre a relação problemática desta figura de Queer Nation (Nação Queer) com a de "ilegalidade" migrante e de migrantes não documentados queer, ver Fernandez (1991). 
conceito de abjeto como "algo rejeitado do qual não nos separamos". Embora ela represente este conceito em termos de "o objeto descartado", o abjeto não é, na realidade, um objeto propriamente externo. Torna-se difícil diferenciar completamente o self do abjeto que se procura eliminar. Portanto, uma vez que nunca pode ser realmente eliminado, o abjeto "não cessa, desde o exílio de desafiar o seu mestre", e sua ostensiva "exclusão" só leva o sujeito "para o lugar onde o significado entra em colapso". A força distintamente perturbadora do abjeto envolve aquilo que "perturba a identidade, o sistema, a ordem. Aquilo que não respeita as fronteiras, os lugares, as regras. O meio-termo, o ambíguo, o misto" (1980/1982, pp. 1-4; cf. Chow 2001; De Genova 2008). A mobilização política dos migrantes, em 2006, implicou o tipo de irrupção abjeta a que Kristeva se refere - expondo uma subjetividade abjeta que, como Peter Nyers (2003) criteriosamente sugeriu, apresenta "uma anomalia preocupante para a ordem soberana" (p. 1090). Ao articular demandas políticas e fazer reivindicações e, desta forma, produzir ou reconfigurar os espaços da política (pp. 1070-1071), os migrantes, ao se manifestarem, colocaram "a questão do sujeito falante no centro da atenção" para "provocar questões fundamentais sobre a política [e]... sobre quem pode ser político" (p. 1089). Tais rupturas críticas confrontam (e afrontam) regimes políticos baseados na suposta "impossibilidade" de que, oficialmente, os não-cidadãos, sem direitos, possam assumir a bandeira da quase-cidadania, outorgando-se a autorização de falar, reconfigurando o espaço do público e reivindicando direitos (McNevin, 2006, 2009; Varsanyi, 2006).

Temos assistido a uma proliferação sem precedentes dessas novas figuras ainda "sem nome" e fundamentalmente "inarticuláveis" de agência política. Como Engin Isin (2009) sugere, essas figuras podem ser descritas de diversas maneiras, como "migrantes", "refugiados", "estrangeiros", etc., mas elas fundamentalmente resistem à categorização porque abalam qualquer tentativa de engessar esse protagonismo dentro de categorias dadas e, ao fazê-lo, abalam também as próprias premissas da cidadania (pp. 367-68). Isin procura discernir "um novo vocabulário da cidadania" nestas figuras de "cidadania ativista" e no correspondente "surgimento de novos 'lugares', 'escalas' e 'atos' através dos quais 'atores' exigem a transformação de si mesmos (e de outros) de sujeitos em cidadãos enquanto requerentes de direitos" (p. 368). Ao enfatizar o caráter constituinte da "cidadania entendida como subjetividade política" e dos "atos de cidadania" enquanto atos pelos quais tais sujeitos constroem a si mesmos (pp. 383; cf. Isin, 2008), Isin postula uma noção de cidadania que é sempre incipiente, uma espécie de cidadania por vir, o que poderia servir de fato para descrever algumas das apostas do ativismo migrante com as quais estou interessado. No entanto, é igualmente fundamental reconhecer, pelo menos no que se refere ao vigoroso exemplo dessas mobilizações de 'imigrantes ilegais' de 2006, que esta particular explosão de energias ativistas teve como premissa o difícil fato jurídico da não-cidadania desses migrantes e o consequente fato social da sua 
abjeção mais geral dentro dos espaços da "política", assim como é sancionada pelo Estado. Em suma, houve uma questão política em jogo no movimento de 2006 que ultrapassou a esfera do político, assim como designada pelo Estado norte-americano. O território presumidamente "nacional" dos Estados Unidos foi transposto para um mero local onde a relação social global entre trabalho e capital revelou sua escala e seu âmbito espacial intrinsecamente transnacional. Embora o regime do Estado norte-americano de "ilegalidade" dos migrantes tenha sido a referência imediata e tenha fornecido a ocasião material e prática para a luta, esta foi uma política que, de modo extravagante, tornou provincial o Estado "nacional" norte-americano como tal. Desestabilizando o espaço "nacional" da jurisdição do Estado norte-americano e obrigando o poder do Estado ao confronto em um campo que foi configurado de forma diferente através das mobilizações migrantes de 2006, até mesmo a cidadania foi indiscutivelmente dispensada. Na verdade, eu diria que essas mobilizações têm muito a nos ensinar sobre uma política que se recusa a ser uma política de cidadania ("estrangeiro", "ilegal", "ativista", "rebelde", ou de outra forma).

A abjeção dos migrantes por parte do Estado encontrou uma política de incorrigibilidade que realmente rendeu ininteligíveis categorias de distinção e discriminação do Estado. Assim, ao menos temporariamente, dentro do contexto dessas mobilizações de massa, a "ilegalidade" do migrante e até mesmo a "deportabilidade" foram anuladas. Isso, obviamente, não significa que as autoridades do Estado não poderiam ter abordado um ou outro indivíduo com essas finalidades. Não se trata também de sugerir que qualquer um dos migrantes engajados na luta poderia jamais imaginar, mesmo que por um momento sequer, que as duras consequências decorrentes de sua condição migratória poderiam ser tão ansiosamente superadas. Pelo contrário, o que se quer afirmar é que as rebeliões em série de dezenas e centenas de milhares, e, finalmente, de literalmente milhões, bruscamente alteraram o equilíbrio de forças e os migrantes emergiram como uma força que podia afirmar: Nós estamos aqui - a despeito de nossa "ilegalidade"; Nós estamos aqui, nós não pedimos desculpas e nós não imploramos por clemência; Nós estamos aqui, nós não nos escondemos - apesar de nossa deportabilidade; Você pode tentar nos deportar - mas você nunca vai se livrar de nós! Esta política de incorrigibilidade, quero insistir, articulou uma política queer de migração. Ou seja, foi uma política que desafiou e rejeitou todas as categorias normativas da soberania do Estado e do seu regime de imigração: Nós estamos aqui, nós somos queer, acostume-se a isso!

Aqui é útil esclarecer e especificar a abordagem epistemológica e política que a categoria analítica queer desenvolve na argumentação deste ensaio. Eu sigo os ensinamentos de Samuel Chambers, que, com um pouco de ironia, sustenta a importância de ser "antiquado" sobre o termo queer (2009, p. 1-2). Como Chambers esclarece, houve "uma constante tendência de equiparar, de forma enganosa, lésbica e gay com queer" e, além disso, uma tendência crescente 
para a redução de queer a um mero termo de inclusão, "uma construção bastante absurda" que se torna "um vale tudo para descrever a identidade de todo e qualquer indivíduo que, de alguma forma, não é agora, ou nunca será, heterossexual". Em vez disso, Chambers expressa a necessidade de "afastar-se essencialmente" da "noção de que queer é um termo de inclusão" e insiste que a política queer é "uma política que identifica e, ao mesmo tempo, continua comprometida com a impossibilidade da inclusão (p. 2; ênfase no original; cf. Gamson, 1995; Phillips, 2009). Chambers segue David Halperin, que sustenta que o termo queer não está precisamente "enraizado no fato positivo da/o escolha/objeto homossexual" e, em vez disso, "adquire seu significado na relação de oposição à norma". Halperin (1995) continua:

Queer é, por definição, qualquer coisa em desacordo com a normalidade, a legitimidade, a hegemonia. Não há nada em especial a que necessariamente se refira. É uma identidade sem uma essência. "Queer", então, não delimita una positividade, mas una posicionalidade vis-à-vis à norma a posicionalidade que não é restrita a lésbicas e homens gays, mas é de fato disponível para qualquer pessoa que esteja ou se sinta marginalizada por causa de suas práticas sexuais... "Queer"... descreve um horizonte de possibilidade, cuja extensão exata e âmbito heterogêneo não podem, em princípio, ser delimitados com antecedência (p. 62; ênfases no original).

Em outras palavras, se a política LGBT - que diz respeito a categorias de identidade sexual, como lésbicas, gays (masculino), bissexuais e transexuais - é uma política voltada para a inclusão de diversas categorias (positivas) de gênero e sexualidade, a relacionalidade negativa da política queer fornece um desafio persistente e uma resistência subversiva contra as hegemônicas e debilitantes categorias normativas de gênero e sexualidade. A política queer, em resumo, é uma política contra-normativa (sexual) da não-conformidade, sem remorsos e antiassimilacionista

A política queer não pretende se integrar dentro de uma determinada economia de distinções normativas e normalizantes, mas visa sabotar e corroer a ordem hierárquica como tal. Como explica Siobhan Somerville, "ancorar as abordagens queer exclusiva ou principalmente à orientação sexual não faz justiça ao potencial alcance da crítica queer, que desestabiliza o terreno sobre o qual qualquer reivindicação específica de identidade pode ser construída" (2002, p. 787). Precisamente por este motivo a política queer pode ser entendida para expressar o que Chas. Phillips apropriadamente descreveu como "uma criatividade turbulenta", que "não cede a... gritos por tolerância, reconhecimento e inclusão" (2009, p. 2). Ao invés de uma forma de política de identidade (sexual), então, a teoria queer almeja, em termos gerais, o repúdio por completo da teoria política liberal baseada na identidade (Chambers, 2009) e, em termos específicos, apresenta uma resposta incorrigível e intransigente à política neoliberal de identidade (Phillips, 
2009). Sem querer dissipar a especificidade sexual da crítica queer como tal, mas seguindo os ensinamentos desses teóricos queer, desejo aqui pedir emprestada a força de desestabilização da política queer para o propósito de explorar uma política de migração que exceda inteiramente os marcos normativos da cidadania e subverta por completo a fetichizada invariabilidade da identidade. Em outros termos, eu quero fazer uma pergunta sobre a política de mobilidade humana, em geral, que coloque em primeiro plano uma prática de liberdade que nunca poderá ser assumida no status constituído (ou até mesmo nas práticas dinâmicas) de cidadania, que enfatize a liberdade como um exercício que não é redutível a algo tão objetivado e delimitado como "direitos" e também que se recuse a se juntar a alguma positiva "identidade", aparentemente naturalizada.

Nesse espírito, e de uma forma muito semelhante ao que estou tentando realizar neste ensaio para o refrão "Aquí estamos", Chambers (2009) procura elaborar uma interpretação "queer" rigorosa do slogan: "Estamos aqui, somos queer, acostume-se com isso!". Em um esforço paralelo com Chambers, busco teorizar o refrão "Aquí estamos" como uma articulação de luta, para perguntar o que o conhecido slogan, associado às mobilizações de migrantes de 2006, pode iluminar sobre a atualidade dessas autênticas lutas de migração. É urgente a necessidade de descobrir o que esta expressão orgânica do movimento pode ensinar para aqueles de nós que teriam a presunção de fornecer-lhe uma formulação teórica adequada, para revelar, de fato, como nossos próprios anseios críticos devem seguir a orientação teórica dessas lutas práticas. Como já tenho sugerido, nem o grito do migrante, nem aquele do movimento queer se articula como uma demanda ou um apelo; nem faz qualquer pedido de inclusão. Na verdade, como Chambers explicita, não é devidamente compreensível em termos de uma dialética negativa de reconhecimento, que iria "correr o risco de reduzi-lo a uma fórmula-padrão de política de identidade das minorias" (p. 17n5). Práticas sexuais e prazeres queer manifestam uma espécie de liberdade não-conformista e não-compatível que, dentro da ordem sociopolítica do patriarcado heteronormativo, só podem ser classificados como um exagero abjeto, gerado sistemicamente pela ordem da hierarquia naturalizada de distinções e discriminações. Nem sequer são propriamente "sexualidades" objetivadas enquanto tais que poderiam, assim, ser "incorporadas". A injunção queer "Acostume-se a isso", conforme afirma Chambers, "não é um pedido de reconhecimento como normal, mas sim uma insistência de que o desvio do normal irá persistir. Afinal, 'nós' - ou seja, aqueles que ouvem o refrão - devemos nos 'acostumar' precisamente ao fato de que 'eles' são queer não são como nós e nunca o serão" (p.12). Os desafios da radical incorrigibilidade, aqui, não implicam simplesmente uma transformação "progressista" do que é considerado "normal", mas sim uma abolição definitiva de toda normatividade. De forma análoga, no refrão da mobilização migrante, a afirmação "não vamos sair" e, ademais, a promessa de voltar no caso de expulsão, equivale a uma declaração de 
que, mesmo em caso de uma abolição total e universal das fronteiras do Estado, a "ilegalidade" não pode ser eliminada em nenhuma circunstância.

Ao lado de outras demandas (mais especificamente, a demanda sempre contingente e inerentemente parcial por "legalização"), neste caso havia uma garantia cacofônica e incongruente de que a "ilegalidade" dos imigrantes indocumentados é endêmica e sem dúvida irá persistir dentro da ordem sociopolítica da soberania do Estado-nação e do fortalecimento das fronteiras. Assim, muitos migrantes, especialmente os não documentados, poderiam adotar uma sincera, sóbria e, acima de tudo, realística avaliação do fato sociopolítico de sua impiedosa abjeção. Portanto, eles audaciosamente rejeitam os implausíveis mandatos utópicos do assimilacionismo em favor de uma irredimível (não-normativa) política queer. Ou seja, em vez de buscar o reconhecimento ou a exoneração, esta abordagem do movimento afirmou de forma ousada: Nós estamos aqui, somos ilegais, acostume-se com isso! Ao invés de uma política de cidadania e inclusão, então, este refrão da mobilização migrante desmascarou o bairrismo intrínseco de qualquer formulação de cidadania.

\section{Incorrigibilidade: a política de anti-identidade}

As tentativas recentes de revigorar a contínua teorização da política queer de forma específica, os ensaios de Chambers e Phillips que eu citei - receberam um legado elucidativo do trabalho filosófico de Jacques Rancière (1992, 1995, 2004, 2006). Para Rancière, a genuína categoria "política" é considerada algo relativamente raro e extraordinário. Não remete apenas a arenas em que os indivíduos exercem seus interesses concorrentes, disputam recursos e, em sentido contrário, se engajam reciprocamente dentro de determinados parâmetros de um sistema dominante de distribuição a fim de obter mais poder, riqueza, reconhecimento ou prestígio. Esta esfera é o que Rancière, de forma variada, chama de "ordem", "contagem", ou mais incisivamente, "polícia". Política, por outro lado, ao invés de participação neste plano da ordem, refere-se ao rompimento radical de tal ordem, precisamente pelas intervenções indesejáveis e inconvenientes daqueles que, literalmente, não têm lugar dentro dela, os que, do ponto de vista da ordem, realmente não existem, aqueles que incluem "uma parte que não tem nenhuma parte". Rancière resume sua compreensão do seguinte modo:

Você pode contar a comunidade como a soma de suas partes - de seus grupos e das qualificações que cada um deles possui. Eu chamo esta forma de contar polícia. Você pode contar um suplemento à soma, uma parte daqueles que não têm parte, que separa a comunidade de suas partes, lugares, funções e qualificações. Esta é a política... (2004, p. 305; grifos no original).

"Sujeitos políticos", portanto, são verdadeiramente políticos, para Rancière, apenas na medida em que são "sujeitos excedentes". Como ele explica: "eles registram a contagem dos incontáveis como um suplemento" (2004, p. 
305). O "suplemento" é uma espécie de excesso: ele ultrapassa os limites e as restrições da ordem existente.

Desse ponto de vista, então, a política genuína tende a ser excepcional, extraordinária e intrinsecamente inquietante. Só pode haver política, portanto, em relação a queer e à incorrigível incoerência que produz uma crise dentro da suposta "ordem" normativa da "existência" normal. Como Phillips acrescenta, em sua elaboração da distinção de Rancière:

Um momento político é testemunhado apenas quando surge uma discrepância entre, por um lado, a contagem de diferentes partes na ordem e, por outro lado, a existência das referidas partes. Esta discrepância resulta em um confronto entre uma parte ou ordem que existe e outra que não existe. A discrepância remodelada dentro da ordem escapa à medição normal das coisas e vem à tona em um momento particular, expondo este erro de cálculo das partes equivalente ao todo... A ordem é o pano de fundo a partir do qual a política surge, reconstituindo o desmembramento das partes $(2009$, p. 3).

É importante ressaltar que a política para Rancière se traduz em uma ruptura que se revela quando "aqueles que não têm parte" paradoxalmente se manifestam como a parte não-contada, o que produz uma crise de ordem por expor uma fissura dentro de seu tecido (1995/1999, pp. 14-15). Na verdade, esta construção tem uma marcante ressonância na formulação do abjeto de Kristeva como a parte "rejeitada da qual não nos separamos", desarranjando, assim, o sistema e a ordem, e ameaçando a identidade e seu significado. Da mesma forma, o tema da não-existência de Rancière se articula bem com a elaboração elucidativa de Susan Coutin sobre a "ilegalidade" migrante como decorrência de um espaço jurídico de "não-existência", onde a presença (ou existência) física e mental dos migrantes não documentados é contrariada e viciada pela sua negação oficial e pela eliminação sistêmica de sua personalidade jurídica (2000, pp. 27-47, 2003).

A revolta daqueles que não são considerados parte do todo aponta 0 erro de cálculo e o proclama como algo errado e, ao fazê-lo de acordo com este esquema, aqueles que, literalmente, não são contados evocam-se à existência ao assumir uma aparência inapropriada dentro da ordem que agora foi interrompida e que se tornou instável. Isso é aquilo que, conforme minha argumentação, estava em jogo nas mobilizações migrantes de 2006, em que aqueles que eram considerados como pessoas cuja existência não implicaria nenhuma consequência para a ordem existente das coisas atestaram uma surpreendente existência (Aquí estamos!), que expôs uma discrepância na ordem policial da soberania do Estado, da cidadania e do mercado. No entanto, é fundamental aqui perceber que, para Rancière, os que não são contados não pedem simplesmente para ser contados (incluídos). Na verdade, a própria capacidade de fazer tal solicitação indicaria que eles já foram incorporados como parte da contagem, ainda que de forma 
claramente desfavorecida ou subordinada: esta é a rotina das disputas comuns sobre a desigualdade. Como Phillips explica:

Fazer um pedido desta natureza exigiria não só o reconhecimento mútuo da existência de partes sem uma parte, mas também uma linguagem comum entre os "sem parte" e a ordem hegemônica... a contagem diz respeito a todo aquele que existe, não a todo aquele que está incluído... Tanto os que têm como os que não têm entram na contagem; o tipo de desacordo entre eles é de uma natureza diferente... De fato, a desigualdade dentro da contagem é resultado de uma igualdade mais profunda: todos aqueles que estão na ordem são igualmente existentes (2009, p. 4).

Queerness, então, aufere sua força política/queer exatamente a partir de uma espécie de ininteligibilidade dentro da ordem (Chambers, 2009), e é especificamente fundamentada "no conflito incomensurável sobre a contagem. O policiamento é a tentativa de eliminar esse conflito" (Phillips, 2009, p. 3). É por essa razão que queerness não pode ser reduzida apenas a uma categoria genérica que visa uma inclusão, senão seria pressionada pela proliferação de identidades sexuais positivas, como "gay" ou "transgênero". O que torna a política queer, tanto especificamente queer e distintamente política nessas leituras de Rancière, é a sua negatividade. Este, aliás, é o motivo pelo qual a desajeitada noção liberal de "tornar queer o Estado" (Duggan, 1994) é profundamente equivocada (cf. por exemplo Puar, 2007; Puar \& Rai, 2002) ${ }^{10}$.

Queerness (ao contrário de "homossexualidade", por exemplo) afirma, com ousadia, a existência de algo fundamentalmente incompreensível, incomensurável, incompatível e, finalmente, inassimilável. $\mathrm{E}$, de fato, o que torna isso politicamente relevante é o irredutível fato que é incorrigível. Como tenho procurado demonstrar, esta é exatamente a mesma posição valente e ousada que as mobilizações migrantes adotaram como seu gesto mais característico: Nós estamos aqui, nós somos ilegais, acostume-se com isso! Ou, nos termos de Rancière: Nós somos a parte que não tem nenhuma parte; no entanto, nós estamos aqui, nós existimos - e nós não vamos a lugar nenhum! De fato, outro refrão da mobilização dos migrantes invoca as divergências e as ambivalências que são sugeridas pela problemática da "contagem" de Rancière: No somos uno, no somos cien; Somos millones; iCuéntanos bien!11 Poder-se-ia detectar aqui a presença ativa de uma noção mais prosaica e previsível do desejo "democrático" de ser contado e, portanto, algo como uma política prefigurativa de cidadania incipiente (talvez rebelde, mas, ainda assim, estritamente inteligível de acordo com a lógica normativa da ordem política hegemônica). Nesta

\footnotetext{
${ }^{10}$ A política queer, de fato, é desafiada mais do que nunca a subverter a mercantilização neoliberal de "queerness" como uma identidade, e, além disso, a repudiar rigorosamente o alistamento normalizado de um "ser queer" domesticado a serviço de projetos neo-nacionalistas que aspiram acima de tudo aos migrantes "queer" (especialmente o muçulmano, como "intolerante", inadequadamente "iluminado", insuficientemente "moderno" e "secular", e assim por diante).

${ }^{11}$ Sou muito grato a Ayça Çubukçu por chamar minha atenção para esta analogia.
} 
perspectiva, seria um gesto análogo ao extremamente controverso slogan, "Hoje nós marchamos, amanhã votamos". No entanto, há também um tipo de artimanha ameaçadora que desafia a ordem da polícia: Conte-nos - SE você puder! De acordo com esta lógica mais incorrigível, a multidão migrante reconhece a racionalidade política da "contagem" apenas para realçar o seu flagrante e vistoso desrespeito a ela. Aqui, os migrantes efetivamente anunciam (e demonstram) sua própria incontabilidade. Anunciar "Nós somos milhões", na realidade, não visa estipular uma contagem efetiva (literal) e sim incentivar o colapso da contagem oficial. Afirma-se a impossibilidade de contar esta parte nociva, mas inconfundivelmente enorme, que não tem parte dentro da contagem. Tal desafio acompanha a afirmação paralela de que a massa, sempre deportável, de imigrantes não documentados é tão inumerável que, na verdade, nunca poderia ser expulsa (deportada), sob quaisquer circunstâncias. Mais especificamente, no entanto, esta afirmação agrava uma situação real na qual a enumerabilidade se tornou ininteligibilidade e em que os migrantes podem proclamar, com ousadia: Nós não estamos indo a lugar algum; você não pode se livrar de nós.

O "nós" em questão nesta política queer de migração, no entanto, não afirma a existência de um eleitorado real. Apesar dos slogans agressivos - como "Hoje marchamos, amanhã votamos" - que para a grande maioria dos imigrantes não documentados é totalmente implausível, e, portanto, facilmente identificável como fantasioso e vazio - muitos daqueles que se manifestaram nas ruas em protesto não foram para serem facilmente reconhecidos como qualquer tipo de bloco eleitoral dentro da ordem existente do Estado norte-americano. Tampouco o "nós" que os migrantes afirmaram expressa a existência de uma "identidade" como tal. Com certeza, dentro das multidões migrantes, havia uma significativa heterogeneidade, composta por um vasto conjunto de categorias raciais e de origem nacional específicas e sub-categorias de identidade "estrangeira" (ainda que os Latinos - e, mais especificamente, os mexicanos - tenham assumido um papel preeminente). Não se pode negar, por outro lado, que determinados esforços organizativos visaram precisamente afirmar que estas energias rebeldes dos migrantes poderiam e deveriam ser domesticadas, objetivando vários projetos políticos minoritários mais previsíveis. Mas, ser imigrante - e ser imigrante "ilegal", em particular - é uma identidade relacional (constituída em e através de uma relação social definitivamente contingente) e, neste sentido, negativa. Não há nada de positivo, essencial ou coeso sobre o que poderia surgir em torno de qualquer tipo distinto de "grupo" ou "população" e é crucial evitar rigorosamente a armadilha de endossar noções culturalistas de uma genérica "experiência imigrante" (o que já designei, em outros lugares, como "essencialismo imigrante" (cf. De Genova, 2005, pp. 56-94). Em vez disso, o status migrante ("autorizado" ou "ilegal") implica um espectro de relações jurídicas e sócio-políticas para o Estado e deve ser ativo e mais ou menos deliberadamente produzido mediante a lei e sua aplicação. Desta forma, 
um queer e variado leque de diferentes identidades chegou a ser agrupado através da mera existência de atributos comuns de pertencimento, ainda que de forma casual, naquela categoria que é a parte que não conta - a dispensável, sempre descartável massa de migrantes - com uma personalidade jurídica rebaixada, insignificante ou ilegal que seja, os quais, do ponto de vista da ordem dominante da cidadania, simplesmente não existem.

As exuberantes e veementes proclamações destes migrantes de sua existência - seu ato de presença ("here"-ness), com certeza, seu ato coletivo de presença ("we"-ness) - e a incorrigibilidade que eles celebraram em sua recusa desafiante a serem silenciados, suprimidos ou expulsos, portanto, só podem ser compreendidas como uma política de anti-identidade. Este "nós", extremamente contingente, não tinha nada de positivo em comum - dentro da ordem política dos EUA - exceto sua relação política negativa com a máquina do Estado, que reduziu todos eles a habitantes sem direitos e, de fato, "suspeitos". Conforme a representação do significado de "queer" de Halperin, esta foi "uma identidade sem uma essência ... não uma positividade, mas uma posicionalidade". Por outro lado, se mesmo assim houve um tipo alternativo de positividade em jogo, ainda que incipiente, ela se consolidou em torno do "nós" que foi compreensível somente dentro da relação social global de trabalho e capital - o positivo "nós" da humanidade trabalhadora, ainda sem nome e, por fim, redutível a não "identidade" como tal (De Genova, 2010b).

Este espaço negativo de relacionalidade, em contradição com a positividade de posições identitárias e questões afins, pode ser associado a outro conceito de Rancière. "Sujeitos políticos", argumenta ele, "... são sempre definidos por um intervalo entre identidades se essas identidades são determinadas pelas relações sociais ou categorias jurídicas... Sujeitos políticos existem no intervalo entre os diferentes nomes de sujeitos" (2006, p. 301; grifo acrescentado). Em outras palavras, de acordo com Rancière, os indivíduos podem ser reconhecidos enquanto sujeitos genuinamente políticos apenas quando eles atuam de uma posição que não é redutível aos termos dados e às coordenadas já conhecíveis e, portanto, às identidades já existentes. Nesse sentido, como Dimitris Papadopoulos e seus colegas (2008) têm argumentado, essas políticas geralmente envolvem uma longa incubação durante a qual elas permanecem relativamente imperceptíveis. Por conseguinte, a política irrompe daquele espaço incipiente e, muitas vezes, fugaz de não-identidade, o intervalo definido pela não-existência: sua erupção é radicalmente nova, até então não-contabilizada, imprevisível e inesperada e ela interrompe a ordem das coisas com um estranho (queer) suplemento, um excesso que, estritamente falando, não pertence e não tem lugar. A política, então, não é, na realidade, uma questão de acomodar e integrar identidades que seriam, de outro modo, prejudicadas, não é uma questão de "inclusão" a qualquer custo. Em vez disso, diz respeito à crise que decorre do aparecimento abrupto 
e problemático daquilo que não existe oficialmente, não pode ser contado ou reconhecido, mas faz reivindicações insubordinadas que são essencialmente ininteligíveis dentro da ordem da polícia: Nós estamos aqui, somos ilegais - venha nos pegar, mas se você fizer isso, vamos voltar logo!

\section{Compulsões nacionalistas e a política global de mobilidade transnacional}

Um verdadeiro estudo crítico da migração deve, de fato, ser destinado não apenas a descrever, mas também a teorizar - e criticar - as atuais lutas e as reais relações sociais de antagonismo não resolvido e de conflito em aberto que continuamente constituem a vida social. Aqui, é crucial especificar que a própria noção de "sociedade" - a reificada e fetichizada "coisa" que tende a ser casualmente chamada de "sociedade" - envolve um pressuposto acrítico em que o "objeto" presumido da análise social é objetivado precisamente em uma escala espacial "nacional" (Hindess 2000; Holloway 1994). Isto é sintomático do que John Agnew (1994) descreveu como um dos efeitos permanentes da "armadilha territorial" do pensamento político contemporâneo. Como Neil Brenner e seus colaboradores observam, "isso estabelece a escala nacional como a fundação ontologicamente necessária da vida política moderna" (2003, p. 2) ${ }^{12}$. Esses problemas epistemológicos e metodológicos são especialmente pertinentes para os estudos migratórios (De Genova, 1998, 2002, 2005; Wimmer \& Glick-Schiller, 2003). De fato, como Willem Schinkel (2010) argumentou, a própria noção de "integração" funciona, de modo geral, como um decisivo e rotineiro curto-circuito através do qual a "sociedade" (territorialmente definida como "nacional") pode ser produzida e estabilizada como um objeto delimitado com determinadas fronteiras, demarcando seu suposto interior do seu constitutivo exterior (cf. De Genova, 2007b). Os próprios processos de formação do Estado e sua nacionalização compulsiva devem, portanto, ser vistos como partes do que é na verdade gerado através das lutas sociais que envolvem a mobilidade humana transnacional e os conflitos políticos de "imigração", em que a figura do "imigrante" é produzida como um objeto do nacionalismo norte-americano (De Genova, 2005, pp. 56-94).

No entanto, essas lutas operam dentro dos parâmetros fetichizados (aparentemente fixos e permanentes) das já constituídas (reificadas) formações do Estado e seus regimes de "legalidade" e "ilegalidade". Todas as migrações, afinal, são constituídas enquanto produtos historicamente específicos das interseções de particulares formações da mobilidade humana (movimentos migratórios) com as diferentes histórias políticas e legislativas de Estados específicos e suas decorrentes

12 Para textos-chave na elaboração de uma crítica explícita do nacionalismo metodológico, ver Giddens (1973; 1985) e Martins (1974). Para uma avaliação retrospectiva e uma crítica de versões contemporâneas desses argumentos, particularmente aqueles associados ao trabalho explicitamente "cosmopolita" de Ulrich Beck (2000; 2002), como uma nova "ortodoxia" sociológica sobre a globalização, consulte Chernilo (2006; 2007). Ver também Beck e Sznaider (2006). 
economias legais de significado e diferenciação (De Genova, 2002). Um dos elementos que está em jogo nessas lutas, no entanto, não é nada menos que o próprio Estado. Pois, a subordinação do trabalho migrante (deportável) é uma tarefa decisiva e constante na mediação expressamente "política" (através dos Estados "nacionais" territorialmente definidos) da relação capital-trabalho global (De Genova, 2010a, 2010b; cf. Holloway, 1994). Assim, este ensaio até aqui tem se referido às mobilizações de 2006, quase sem problematizar, como tendo ocorrido e sido substantivamente localizadas "nos Estados Unidos". Mas é muito relevante notar que este movimento, ainda que preocupado principalmente com o horizonte legislativo que afeta o status jurídico dos migrantes dentro do espaço do Estado-Nação norte-americano, teve repercussões transnacionais e desdobramentos, inspirando mobilizações paralelas em muitos outros lugares em toda a América Latina (Robinson, 2006). Ainda mais importante, a luta desses migrantes transnacionais interveio de forma radical na (re)composição em curso da cronologia e do teor da política de "imigração" do Estado norte-americano e do processo legislativo. Assim, o que está em jogo aqui não é simplesmente a análise dos processos sócio-políticos "nos" Estados Unidos (como se pudessem ser compreendidos como efetivamente contidos dentro de um recipiente resistente conhecido como "sociedade" norte-americana), mas sim a teorização crítica de uma relação social transnacional de trabalho e capital e a política global de mobilidade migrante como constitutiva dos Estados Unidos como tal (De Genova, 2007b). A análise crítica das lutas migrantes de 2006, portanto, pode iluminar questões mais abrangentes da especificidade histórica dos Estados Unidos - na atualidade - como a formação do Estado, das manifestações particulares de sua política de imigração, do nacionalismo e nativismo norte-americano e de toda a gama de suas compulsões nacionalistas.

Além disso, o que se manifesta aqui como uma luta eminentemente "política" entre os migrantes e o Estado norte-americano, em particular, deve ser sempre interpretada, simultaneamente, como uma mobilização insubordinada do trabalho migrante (transnacional) contra os termos de sua subordinação ao capital (global). Não é sustentável imaginar que esta revolta abertamente "política" dos migrantes "nos" Estados Unidos seja, de alguma forma, uma questão irrelevante para o capital. As compulsões nacionalistas, através das quais a política tende a ser disputada em lutas reais, especialmente no que diz respeito à "imigração" dentro do espaço de um Estado "nacional" específico, devem ser sempre criticamente conceituadas em termos de política global da relação capitaltrabalho. A este respeito, a mobilidade transnacional do trabalho - como todo o trabalho no contexto do capitalismo - necessariamente tem um duplo caráter, como (efetivamente subordinado) trabalho em-favor-do-capital e, ao mesmo tempo, potencialmente, trabalho contra-o-capital, pois nunca é pré-determinado e permanece sempre imprevisível e volátil. 


\section{"Ilegalidade" e incorrigibilidade}

A fracassada Lei de Proteção das Fronteiras, Antiterrorismo e Controle da Imigração llegal claramente teve como foco central a migração não documentada e os "estrangeiros ilegais". Previsivelmente, portanto, as exigências propositivas do movimento de protesto frequentemente incluíram várias solicitações de "legalização" de imigrantes em situação irregular. No entanto, a proposta de Lei, de forma específica, incluía disposições não só para a clara e sumária criminalização dos não documentados, mas também para a manipulação de aspectos técnicos no corpus da lei de imigração como pretexto para a ilegalização de não-cidadãos "legais" (e geralmente cumpridores da Lei). Tais disposições procuraram, ativa e agressivamente, ofuscar a linha clara de demarcação entre "legalidade" e "ilegalidade, ou seja, a favor de uma enorme degradação da condição social e política de todos os migrantes. Assim, as características abertamente punitivas e repressivas do projeto de Lei serviram para instigar uma improvável integração e coesão entre categorias de migrantes juridicamente diferentes, o que anteriormente poderia ter sido efetivamente evitado pelas dimensões individuais e divisórias da economia de distinções e discriminações da Lei de Imigração. Desta forma, um tipo improvável de "nós" se solidificou precisamente através da negatividade deste ato comum de recusa. No entanto, o foco principal de todos os protestos, como consequência, foi de denunciar, simples e audaciosamente, a Lei de Imigração supostamente "antiterrorista". Isso significa que grande parte do conteúdo real dos protestos adquiriu um claro tom de queixa.

O caráter predominantemente defensivo da luta era amplamente evidente na abundância de slogans que revelavam, de forma significativa, a sensibilidade mais acuada do movimento, como as proclamações vigorosas e previamente assumidas, Não somos terroristas e Não somos criminosos. Essas queixas dos migrantes são inerentemente prejudiciais, a meu ver, porque ao responder às alegações ofensivas da metafísica dominante nativista de suspeita, eles são induzidos a assumir o mesmo terreno discursivo. Suas posturas estritamente defensivas dentro desta arena do discurso os obrigam inevitavelmente a verificar suas premissas e defender seus conceitos: em suma, eles parecem responder que há realmente migrantes "suspeitos", que as afinidades entre "crime", "terrorismo" e "imigração" são genuínas, palpáveis e as preocupações legítimas - no entanto... "somos inocentes!". Portanto, esses migrantes reagem afirmando que a conjuntura da metafísica antiterrorista do Estado de Segurança Interna sobre a "imigração ilegal" foi simplesmente equivocada e desorientada. Esses tipos de respostas pareciam dizer: "Podemos ser 'ilegais' mas, por outro lado, somos verdadeiramente inocentes, bons, dignos e, com efeito, 'imigrantes' legítimos". No pior cenário, alguns migrantes (Latinos) durante as mobilizações de 2006 ainda se ofereceram como cúmplices da ostensiva "guerra contra o terrorismo" do estado de segurança: eles se colocaram como conselheiros, agitando cartazes que, com um pouco de ironia, declaravam: Os sequestradores do 
9/11 não falavam espanhol. Assim, ao lado e contra as políticas que promoveram um "nós" amplo e negativo (anti-identitário) que abrangia toda a gama do que é deportável, havia uma política de identidade positiva, especificamente Latina (e, neste caso, reacionária) de denunciar os "terroristas" como não-cidadãos, que "não falam espanhol". Apesar do transparente sarcasmo, esses tipos de gestos só poderiam confirmar novamente a presumida sacralidade da missão de combate ao terrorismo que até então tinha se tornado o mandato primordial das autoridades de imigração. E reafirmaram a insinuação dominante de uma lógica racializada da suspeita e da culpabilidade que representou o árabe e outros não-cidadãos muçulmanos como inimigos estrangeiros (De Genova, 2007a; cf. Ahmad, 2002, 2004; Bayoumi, 2008; Cainkar, 2002, 2003, 2004, 2005; Chon \& Arzt 2005; Cole, 2003, pp. 47-56; Daulatzai, 2007; Fernandes, 2007; Human Rights Watch, 2002; Maira, 2004, 2009, 2010; Puar, 2007; Puar \& Rai, 2002; Saito, 2001; Volpp, 2002).

No mesmo espírito de conformidade com o ethos dominante de um nacionalismo norte-americano assediado, mas reanimado, houve igualmente um esforço extraordinariamente barulhento e enfático, nas lutas de 2006, em favor de aspectos mais conservadores ao insistir que os manifestantes deveriam carregar bandeiras dos EUA, como um sinal de "lealdade" e como um testemunho do desejo assimilacionista de "se tornarem americanos" de verdade. Nesses debates dentro do movimento a referência explícita era a profusão habitual de bandeiras representando os diversos países de origem dos migrantes, o que supostamente serviu apenas para confirmar as piores suspeitas nativistas dos lobbies anti-imigrantes (cf. Baker-Cristales, 2009; Pulido, 2007). Mais controverso, mas da mesma forma comprometido com as prerrogativas nacionalistas norte-americanas, foi o lançamento, em 28 de abril de 2006, de "Nuestro Himno", uma versão em espanhol de "The Star-Spangled Banner" (o hino nacional dos Estados Unidos). A canção, distribuída para emissoras de rádio de língua espanhola na véspera das manifestações de $1^{\circ}$ de maio, foi destinada a ser utilizada como um hino de solidariedade para o movimento e foi rapidamente desacreditada enquanto prova do repúdio antiassimilacionista da genuína "americanidade". A colunista anti-imigrante Michelle Malkin, por exemplo, depreciou a canção como sendo "o Hino do estrangeiro ilegal"13. A "ilegalidade" migrante, então, continuou a ser o núcleo duro em torno do qual circularam todos esses concorrentes e conflitantes projetos de negociação das fronteiras da identidade nacional norte-americana, seja vigiando e fiscalizando os altos preços da intolerância e da hostilidade nativista, seja magnanimamente procurando "assimilar" o icônico "mau imigrante" (os não documentados), na aura xenofílica do proverbial

${ }^{13}$ George W. Bush respondeu à consulta de um repórter com a observação: "Acho que o hino nacional deve ser cantado em inglês. $\mathrm{E}$ eu acho que as pessoas que querem ser cidadãos deste país devem aprender inglês e aprender a cantar o hino nacional em inglês" (Montgomery, 2006). No entanto, um relato posterior revelou que o próprio Bush pode ter cantado o hino em outras versões no idioma espanhol, e de qualquer forma, tinha aparentemente tolerado a sua utilização durante suas propostas de campanha em direção a círculos eleitorais latinos (Baker, 2006). 
"bom" migrante, que serve para comprovar para o nacionalismo norte-americano a resiliente escolha honrada de uma "América imigrante" (Honig, 1998, 2001, pp. 73-106; cf. De Genova, 2005, pp. 56-94).

A luta dos migrantes de 2006 foi, assim, pressionada a responder à fetichização permanente e sempre mais fanática da "ilegalidade" enquanto uma odiosa afronta e imperdoável transgressão da sacralidade do espaço do Estado. No entanto, precisamente por essa razão, a outra política do movimento, com sua vigorosa, repetida e insistente declaração - Aqui estamos e nós não vamos sair! $E$ se eles nos expulsarem, vamos voltar logo! - exige uma séria reflexão. Pois, esta outra política foi, de fato, a (antiassimilacionista) política de alteridade irredutível e incorrigível da luta migrante. Esse slogan é facilmente compreensível dentro do contexto "nacional" dos Estados Unidos e pode até mesmo ser utilizado para vários projetos assimilacionistas mais convencionais: Nós estamos aqui, nossa inclusão já é um fato irreversível, por isso nossa integração e assimilação devem ser adotadas; de toda forma, elas são inevitáveis. Mas há uma radical questão aberta aqui, que adia e efetivamente silencia completamente a questão da assimilação como sendo irrelevante: O que quer que possamos nos tornar, nós não vamos a lugar nenhum - aqui estamos, aqui e agora.

Além disso, é útil reformular esta afirmação da presença migrante literalmente uma substancial presença física e social dentro do Estado Nação dos EUA - assim como a proclamação de uma mobilidade global. Afirma-se abertamente o fato de estar "aqui" sem nenhum remorso e, ao mesmo tempo, a promessa de voltar apesar da deportação demonstra, por implicação, uma espécie de ubiquidade que é realizada em e através da mobilidade - declara-se, de fato: Estamos em todos os lugares. Na verdade, o desafio que os migrantes nos Estados Unidos apresentaram e a resiliência que eles celebraram equivale a anunciar: Somos livres em nosso movimento e através do nosso movimento-e por meio de nossa mobilidade, iludimos seus esforços para controlar o nosso movimento e conter nossa liberdade. Aqui, em suma, houve uma política de migração que excedeu a "política" estabelecida de "imigração", uma política global de mobilidade transnacional, um excesso que não podia ser domesticado e que se recusou a ser encarcerado dentro do espaço do Estado-nação norte-americano. Desse modo, a efetiva presença migrante dentro do espaço do Estado norte-americano foi, assim, conjugada com a potencialidade onipresente de mais migração, sinalizando o horizonte global de uma "presença" migrante além das fronteiras do Estado, que permanece sempre possível e apenas aguarda a sua própria mobilização como migração-de-fato (De Genova, 2010b). Neste caso, em outras palavras, houve uma vibrante manifestação da autonomia da migração ${ }^{14}$. Portanto, ao lado de numerosos outros esforços mais convencionais para

${ }^{14}$ Estas reflexões se devem a conhecimentos teóricos e a perspectivas críticas associados a estudiosos da "autonomia da migração", ver, por exemplo: Mezzadra (2001, 2004, 2006, 2010); Mezzadra e Nielson (2003); Moulier Boutang (1998, 2001); Moulier Boutang e Garson (1984); cf. De Genova 
desviar as acusações de "não-merecimento" associadas à "ilegalidade", ocorreu aqui uma afirmação entusiasmada e persistente da mobilidade migrante e uma verdadeira assunção do fato da "ilegalidade" em si. Assim, esse slogan suspendeu por completo a compulsória questão nacionalista da "assimilação", negando sua pertinência e repudiando sua validade: Nós somos quem somos e o que somos; nós estamos aqui e não há nada que vocês possam fazer sobre isso. Além disso, eles pareciam assegurar às autoridades: Estamos aqui hoje, podemos estar lá amanhã, mas estaremos de volta aqui novamente - peguem-nos se puderem! Simplificando, foi uma proclamação exuberante de incorrigibilidade. Como alguns migrantes tornaram explícito: Somos ilegais, e daí? (McNevin, 2009, p. 74; para exemplos similares nos anos 1990, veja De Genova, 2005, pp. 238-239).

\section{"Direitos dos imigrantes"... e migrantes sem direitos}

No início deste ensaio eu deliberadamente apresentei os dois refrões - Aqui estamos... e Nós estamos aqui, nós somos queer... - não como slogans de "direitos dos imigrantes" ou "direitos dos homossexuais" (muito menos, "direitos queer"), mas sim como as respectivas manifestações da mobilização migrante e queer. Ou seja, esses slogans se deflagraram a partir de mobilidades que não podiam ser fixadas em um lugar, categorizadas ou regulamentadas. Eles dizem respeito a práticas e processos em aberto que ativamente produzem e transformam o espaço, e não a identidades fixas ou "objetos" conhecíveis para serem colocados em seus devidos lugares. Além disso, enfatizei a importância e a relevância, para fins interpretativos e analíticos, do fato de que nenhum refrão desenvolve algo em relação a uma demanda. Nenhum slogan é um pedido por "direitos" e nem um apelo, de forma simples ou direta, por "reconhecimento" (muito menos, por "representação"). Para acompanhar ainda mais a lógica da discussão anterior de Rancière, estas são declarações políticas justamente porque elas não buscam a inclusão dentro da ordem existente de direitos e privilégios e nem sequer procuram ser compreensíveis dentro desse quadro de pressupostos. Na medida em que, por meio desses slogans, "imigrantes ilegais" e queers ficam satisfeitos simplesmente em anunciar a sua existência e corajosamente afirmar a sua presença abjeta - seja como for, apesar de todas as possíveis recriminações e repercussões - eles atuam de acordo com uma perspectiva totalmente diferente, uma lógica antiassimilacionista de luta, para a qual e através da qual a liberdade é uma prática realizada pelo seu próprio exercício. Ao invés de reivindicar direitos, essas manifestações complementam os antagonismos irreconciliáveis com a alteridade incorrigível. Não há a pretensão de uma possível reconciliação. Elas são a irrupção de dentro de um irredutível "de fora", um excesso inassimilável, que não busca a integração de sua própria abjeção abominável dentro do sistema. Desta forma, elas ameaçam esse sistema com o colapso de seus próprios

(2009; 2010b); Karakayali e Rigo (2010); Papadopoulos, Stephenson, e Tsianos (2008). 
significados normativos e sua coerência. Além disso, se houve reivindicações mesmo que apenas implicitamente - trata-se daquelas reivindicações que, em última análise, exigem o completo colapso de toda a ordem normativa.

Em um contexto sociopolítico marcado pela agressão legislativa contra as aparências residuais da personalidade jurídica dos migrantes, pela crescente militarização das fronteiras e pela intensificação dos esquemas de segurança, a própria noção de "direitos dos imigrantes" é, na verdade, bastante estranha, se não completamente paradoxal. De fato, a ideia de "direitos dos imigrantes", de modo instrutivo, expõe algumas das contradições constitutivas do regime da própria cidadania e, mais em geral, dos "direitos" (De Genova, 2007a, 2009, 2010a, 2010b). Como eu gostaria de explicar nesta seção final, o que designei como sendo a política queer de migração se articula ao lado de - mas, fundamentalmente, em desacordo com - este conceito polêmico de "direitos dos imigrantes". Se as mobilizações dos migrantes de 2006 comprovaram alguma coisa, foi, de forma evidente, que aqueles não-cidadãos deportáveis, esses moradores migrantes oficialmente relegados a um status jurídico e a uma condição social de descarada e miserável privação de direitos, nunca poderiam ser despossuídos, de forma tão simples, de suas prerrogativas políticas e de seus recursos resilientes para a luta. Seu empoderamento e suas capacidades criativas, enquanto forças genuinamente políticas, não eram redutíveis a sua posição oficial (jurídica) de deficiência, como explícita e ingenuamente estipulado dentro da ordem da polícia.

É previsivelmente sintomático da luta política nos Estados Unidos, de forma específica, que as mobilizações de migrantes pareciam estar focadas quase exclusivamente sobre essas questões legalistas de "direitos", "ilegalidade", "anistia", "legalização" e, de modo geral (mas apenas no seu registro estritamente jurídico), de cidadania. Ou seja, as mobilizações de migrantes foram celebradas rapidamente, talvez prematuramente, e sem muita reflexão crítica - como um "novo movimento de direitos civis" (cf., por exemplo Chacón \& Davis, 2006, p. 7; Johnson \& Hing, 2007), apesar da evidente inadmissibilidade dos migrantes para qualquer um dos direitos supostamente inerentes a todos os cidadãos. No entanto, praticamente nunca houve qualquer disputa sobre as efetivas condições sociais de marginalização dos migrantes, sua privação material e miséria real. A pobreza foi um tema bastante periférico, se não completamente silenciado, nesses debates. De forma específica, os tipos de disputas sobre o empobrecimento generalizado dos migrantes enquanto "minorias" racialmente subjugadas, que podiam estar relacionados às clássicas controvérsias dos "direitos civis" relativas à cidadania "de segunda classe", foram simplesmente ignorados e considerados irrelevantes. Aqui, podemos lembrar a terminologia preferida pelo nativismo anti-imigrante dominante: "Qual parte de 'ilegal' você não entende?". Assim, contra a argumentação hostil de que a "ilegalidade" do migrante torna qualquer reivindicação por "justiça" efetivamente infundada, advogados pró-imigrantes 
têm a tendência de contornar essas questões sociais em favor de uma sincera fé na "legalização". Écomose algum tipo de remédio meramente jurídico para a condição (deportável e sem direitos) "ilegal" dos migrantes pudesse presumivelmente remover uma onerosa barreira e instantaneamente disponibilizar-lhes o acesso à mítica mobilidade social ascendente das canônicas narrativas nacionalistas norteamericanas sobre a "terra das oportunidades" (Chock, 1991). A este respeito, as preocupações legalistas dessas lutas permaneceram suscetíveis à hegemônica xenofilia, na frase esclarecedora de Bonnie Honig (1998, 2001), que motiva os discursos nacionalistas liberais norte-americanos de "imigração" (cf. De Genova, 2005, pp. 56-94). Assim, os defensores liberais favoráveis à "legalização" dos migrantes e aos "direitos dos imigrantes" poderiam permanecer lealmente fieis (ainda que, talvez, muitas vezes inconscientemente) aos conceitos e pressupostos nacionalistas dos EUA quanto à promessa da "América imigrante" como um refúgio de liberdade e um abrigo de oportunidades sem limites.

Em contraste com a recuperação estatista e nacionalista da rebelião dos migrantes como uma questão de "direitos civis", outros autores viram na mobilização dos migrantes transnacionais uma ocasião para o revigoramento do sentido e o conteúdo dos "direitos humanos". Na verdade, o difundido slogan Nenhum ser humano é ilegal parece suspender a pertinência da "lei" - especificamente, as preocupações mundanas e bairristas das leis de imigração dos Estados-Nação em favor de um imperativo "superior" (moral), baseado no universalismo de um fato material presumivelmente irredutível da humanidade enquanto tal (Agamben, $2003)^{15}$. O fundamento combativo deste slogan responde eficazmente à realidade sociopolítica de alguma ilegalização do status de não-cidadãos migrantes mediante a recuperação dessas pessoas, em particular, (e de suas relações específicas com o poder do Estado, a soberania e as fronteiras) enquanto "legítimos" membros de um círculo eleitoral (humano) universal. Tal slogan, desta maneira, invoca o espectro de uma "lei" que é maior do que qualquer lei imigratória estatal - por implicação, pelo menos, uma "lei" ("natural") que finalmente deve ser fundamentada na pura "natureza" do ser humano ou no nascimento como tal (cf. De Genova, 2010b). No entanto, a questão que talvez seja ainda mais controversa para os propósitos deste ensaio é que esse slogan pode ser lido também para proclamar: Todos os seres humanos são legais. O movimento em direção aos "direitos humanos", então, implica um verdadeiro desejo de legalidade ${ }^{16}$. Nesse sentido, essas melancólicas

${ }^{15}$ Como é notório, o slogan Nenhum Ser Humano é llegal (especialmente associado aos movimentos anti-fronteiras na Europa, incluindo a iniciativa alemã bem estabelecida Kein Mensch ist Illegal) é, às vezes, (como no Canadá, por exemplo), mais comumente enunciado como Ninguém é llegal. Como criteriosamente sugerido por um revisor anônimo deste ensaio, esta última formulação potencialmente introduz alguma ambiguidade adicional, de tal forma que o slogan vem sendo utilizado em nome dos "direitos dos animais" e para outras preocupações dos movimentos ecológicos, comprometidos a transcender a política totalmente humano-centrista.

${ }^{16}$ Para a discussão especificamente relacionada ao desejo ambíguo dos deportados por uma lei adequada, ver Peutz (2007). 
invocações dos supostos "direitos humanos" de migrantes indocumentados (oficialmente sem direitos), na medida em que operam como uma grande afirmação de um etéreo ideal de "legalidade", permanecem aprisionadas dentro da lógica do poder do Estado soberano. Assim, o projeto de configurar as lutas de migração como um icônico paradigma para a defesa dos "direitos humanos", está, em última análise, profundamente enredado no mais pernicioso, e normalmente não estudado, horizonte de uma (supranacional, imperial) soberania global.

Poder-se-ia ler Rancière em apoio a tais afirmações sobre "direitos humanos", mas apenas em uma perspectiva distintamente queer, paradoxal. Como já descrevi brevemente, Rancière concebe a política como o conteúdo de "cenas específicas de dissenso" em que os indivíduos que são considerados oficialmente e paradoxalmente não existentes, contudo, decretam um "suplemento" para a "contagem" oficial da ordem dominante (2004, p. 305). Ele continua afirmando que os Direitos do Homem (ou "direitos humanos", por assim dizer) são de fato nada menos do que os direitos desses sujeitos políticos, aqueles dos "não contados" e que não existem até que eles ativem esse dissenso e perturbem a ordem da polícia. Rancière argumenta que é por esta razão que...

até mesmo os imigrantes clandestinos nas zonas de trânsito de nossos países ou as populações nos campos de refugiados podem invocar [os Direitos do Homem]. Estes direitos são deles apenas quando podem utilizá-los para construir um dissenso contra a negação dos direitos que sofrem. E, entre eles, há sempre pessoas que o fazem (2004, p. 305-306).

Destarte, em resposta à pergunta "Quem é o sujeito dos Direitos do Homem?", Rancière declara que é o sujeito até então não-contado, não-existente e de nenhuma conta. Por conseguinte, o sujeito dos direitos humanos é o "sujeito excedente", que produz um dissenso, um erro de cálculo suplementar, no qual a parte que não tem parte introduz a si mesma e perturba a ordem. A política, portanto, acaba sendo, em grande parte, uma polêmica sobre a comprovação dos Direitos do Homem. Como Rancière explica:

Em última análise, esses direitos aparecem realmente vazios. Eles parecem inúteis. E quando eles não têm mais utilidade, fazemos o mesmo que as pessoas caridosas fazem com as roupas velhas. Damos para os pobres. Aqueles direitos que parecem inúteis em seu lugar de origem são mandados para o estrangeiro, junto com remédios e roupas, para pessoas necessitadas de remédios, roupas e direitos. É dessa maneira, como resultado desse processo, que os Direitos do Homem se tornam os direitos dos que não têm direitos, os direitos de seres humanos nus sujeitos à repressão inumana e a condições de vida inumanas. Tornam-se direitos humanitários, os direitos dos que não podem praticá-los, das vítimas da negação absoluta do direito. Por tudo isso não são vazios. [...] $\mathrm{O}$ vazio é preenchido por outro alguém ou outra coisa. Os Direitos do Homem não se tornam vazios, tornando-se os direitos daqueles que não os podem praticar (2004, p. 307). 
Assim, reconhecendo o aparente vazio de "direitos humanos", Rancière sugere que é precisamente esse vazio que os torna viáveis para aqueles que se mobilizam politicamente desde um espaço de não-existência. A partir de sua observação crítica (e criticando explicitamente o relato clássico de Hannah Arendt [1951/1966, pp. 267-302]), os "direitos", que são substancialmente vazios, não são, de fato, vazios - porque sua substância especificamente política, paradoxalmente, deriva a partir da ativação de um dissenso que irrompe precisamente de um vazio, de uma condição de inexistência. Os direitos humanos são ativados, para Rancière, como os direitos cerceados desses sujeitos políticos cuja inexistência dentro da ordem dominante comprova a contenciosa polêmica que eles iniciam. A partir deste paradoxo, no entanto, a noção por vezes vazia e cerceada de "direitos humanos", pode assumir um significado enigmático, mas que pode ser postulado somente de forma negativa, relacional - de fato, como os "direitos" que contam exatamente porque, e somente porque, eles são os direitos dos sem direitos.

Um paradoxo mais profundo e muito mais perigoso, no entanto, reside na absoluta impossibilidade de tal polêmica sobre "direitos humanos" produzir um material e fundamento prático que não seja colocado em discussão por sua dependência de algum tipo de soberania supranacional, "universal", quase imperial. Pelo menos por implicação, o dissenso que provoca uma nova conjuntura política - na medida em que se articula em termos de "direitos" - também se refere, inevitavelmente, a uma espécie de julgamento. "Ao se tornarem os direitos daqueles que não os podem colocar em prática", para voltar à frase formulada por Rancière, os Direitos do Homem operam em um vazio que nunca deixa de ser "preenchido por alguém ou alguma outra coisa". Como as noções mais metafóricas de ("global", "transnacional") "cidadania", que são definitivamente indissociáveis destas várias formulações de "direitos", qualquer tentativa de capturar energias rebeldes (transnacionais) dos migrantes e verdadeiras práticas de liberdade dentro da rubrica de direitos ou legitimidade está condenada a exaltar novamente algum tipo de ordem jurídica do poder constituído soberano (Estado). Por mais virtual que este último apareça, o mais certo é que este poder seja o de uma potência global que foge a uma definição segundo a mais convencional e territorialmente definida forma "nacional". Se o verdadeiro sujeito de "direitos humanos" é aquele que surge a partir de um espaço de não-existência dentro da ordem da polícia, há igualmente aqueles poderes policiais constituídos que, de forma análoga, não possuem um lugar jurídico sancionado para ativar ou fazer cumprir "direitos humanos" - exceto o suposto monarca (global) que confirma sua própria legitimidade apenas por decidir, de fato, sobre o que considera ou não como um "estado de exceção" (Agamben, 2003). "Estados imperiais", argumenta Ann Stoler, "por definição funcionam como estados de exceção" (2006, p. 139; ênfase no original). Assim, os esforços (como os de Rancière) de recuperar a noção de "direitos humanos" - precisamente 
recorrendo à abjeta figura de habitantes sem direitos de poder soberano - são em última análise insustentáveis. ${ }^{17}$

Aqui, precisamos regressar à questão de uma política global de trabalho e capital que teimosamente resiste ao seu próprio encerramento dentro de qualquer política de "cidadania", seja qual for sua construção. Emaranhados nesta matriz de "direitos" e privação de direitos, os temas acerca do trabalho (transnacional) migrante (e, portanto, da exploração, mesmo que apenas de uma forma um tanto incipiente), foram abundantemente expressados nas mobilizações de 2006 - acima de tudo, na designação culminante do $1^{\circ}$ de maio como um dia nacional de greve geral e boicote de consumidores, conhecido como "Um Dia sem Imigrantes" (cf. De Genova, 2009; Pulido, 2007; Robinson, 2006). O significado do movimento migrante como precisamente uma luta de trabalhadores foi claramente sinalizado por essa revitalização deliberada do Primeiro de Maio como Dia Internacional dos Trabalhadores. É evidente que o $1^{\circ}$ de maio é um feriado da classe trabalhadora mundial. Apesar da data ter origem histórica na cidade de Chicago, em 1886, esse dia de maio tem sido geralmente estigmatizado e suprimido historicamente pelos mandatos do anticomunismo dos EUA e, na verdade, nunca tem sido homenageado nesse país, exceto por movimentos de operários de extrema esquerda. A este respeito, também - justamente porque uma política explícita de luta de classes tem se tornado praticamente inexprimível nos Estados Unidos - a explícita e atrevida política de trabalho de mobilizações dos migrantes implicou, de igual modo, uma política queer.

Recorrendo a um variado leque de declarações sobre dignidade e direitos do trabalho, o movimento de 2006 promoveu um corajoso lembrete para empregadores e consumidores norte-americanos acerca da ampla dependência dos migrantes - enquanto trabalhadores. No entanto, essas vigorosas afirmações de direitos dos migrantes, "direitos" fundamentados em sua laboriosa servidão (e, implicitamente, dócil, obediente e cumpridora da lei), foram também atormentadas por suas próprias contradições. Em particular, uma abordagem muito difundida do discurso migrante a respeito de "trabalho duro" e da "falta de merecimento" ficou profundamente arraigada em um conjunto tortuosamente contraditório de alegações no que diz respeito à "preguiça", à "dependência da proteção social" e à "criminalidade" que muitos migrantes comumente atribuem aos seus concorrentes mais próximos dos escalões inferiores do mercado de trabalho dos EUA, ou seja, cidadãos norte-americanos empobrecidos - "minorias" raciais - acima de tudo, os afro-americanos (De Genova, 2005, pp. 167-209, 2008; De Genova \& RamosZayas, 2003, pp. 57-82). Assim, um corolário das declarações supostamente autoevidentes Não somos terroristas e Não somos criminosos se apresentou em outro binômio: Nós somos trabalhadores, não criminosos e, ainda, no mais revelador:

17 Estou em dívida com Ayça Çubukçu e Engin Isin por me incentivarem, em suas respectivas formas discrepantes, a resolver este problema mais detalhadamente. Para uma crítica relacionada aos "direitos humanos" em relação ao problema do poder soberano, consulte Çubukçu (2008). 
Nós não estamos no Welfare. Quando Jennifer Gordon e R. A. Lenhardt justamente perguntam, em resposta a esses slogans, "Ao contrário de quem?", eles muito apropriadamente notaram que "a retórica aparentemente positiva dos cartazes que muitos carregavam nas manifestações... tinha um doloroso duplo sentido" (2006, p. 2496; ênfase no original). Aqui se pode detectar a transposição de uma política de trabalho como negatividade, enredada, de forma relacional, dentro e, ainda irreconciliavelmente, contra o capital, em uma política identitária de classe e raça, uma política de classe como uma identidade positiva. Neste contexto, o "trabalho" em si atua ideologicamente como um valor "Norte-Americano" dentro de uma economia moral da cidadania, em que a capacidade para o trabalho é associada a uma competência de autocontrole, autogoverno e de cidadania legítima através de uma espécie de política laboral republicana virtual (cf. Almaguer, 1994; Roediger, 1991; Takaki, 1979).

Ainda assim, ao lado desses gestos identitários positivos, houve a articulação de uma outra política - uma política incorrigível do trabalho migrante que assumiu a forma de uma vigorosa política de anti-identidade. Admitindo sua posição de trabalhadores, os migrantes sustentaram com vigor sua presença "ilegal" (e sem direitos) - Aquí estamos! - e as suas mobilizações apresentaram o poder soberano do Estado com uma impensável aberração. Os migrantes contrapuseram às argumentações normativas de "ilegalidade" um quadro alternativo de reivindicações - uma premissa das prerrogativas (globais) de trabalho - que, abnegou, sem reservas, a pertinência de uma Lei de imigração por completo. Falando em uma linguagem política que aparentemente foi dirigida ao Estado, nestas condições, as mobilizações dos migrantes mudaram o foco de incidência enfrentando diretamente o capital, enquanto força de trabalho transnacional. O movimento parecia simplesmente declarar: Aqui estamos nós, "ilegais" e sem direitos, mas porque você depende de nosso trabalho, você é impotente para nos expulsar; assim, nós desafiamos seu poder e não vamos embora ${ }^{18}$. Estamos diante de uma proclamação do trabalho (transnacional) como constitutivo do capital (global), indissoluvelmente dentro do capital, mas também contra o capital - sem direitos, "ilegal", mas, ao mesmo tempo, insubordinado. Como observou Marx, na "antinomia de direito contra direito... a força decide" (1867/1976, p. 344). Assim, a resposta à efetiva situação de falta de direitos dos migrantes não foi o recurso a alguma rubrica alternativa para a restauração dos direitos. Neste sentido, a falta de direitos dos migrantes era meramente um "fato" e o caráter anômalo e inimigo deste fato tornou a lei em si mesma um inimigo abominável. Esse aspecto da política sem remorso do movimento de trabalho (transnacional) migrante, portanto, facilitou uma rejeição implícita da própria noção de "direitos dos imigrantes", o que

\footnotetext{
${ }^{18}$ A partir de outubro de 2009, uma onda de greves de milhares de trabalhadores migrantes não documentados solicitantes de residência legal na França articulou os temas da presença de migrantes e do trabalho em termos muito semelhantes. Seu principal slogan era: "On ici bosse, on vit ici, on reste ici" [Nós trabalhamos aqui, vivemos aqui, vamos ficar aqui]. Sou grato a Sébastien Chauvin por trazer esta analogia à minha atenção.
} 
foi prejudicado por suas próprias inerentes inconsistências e assim comprometido por esta incoerência. Tais gestos efetivamente responderam à linguagem fetichista de "legalidade" e "ilegalidade" com outro idioma que era estritamente incompreensível para os formalismos abstratos da lei e sua economia de distinções categóricas. Esta política do trabalho migrante foi uma política queer, ademais, porque foi ousada e sem reservas em relação a esta ininteligibilidade: ela denunciou a abjeção e a falta dos direitos de migrantes mediante o completo repúdio da lei e do próprio Estado, desafiadora e incorrigivelmente.

\section{Referências bibliográficas}

AGAMBEN, G. (2005). State of exception. Chicago, IL: University of Chicago Press.

AGNEW, J. A. (1994). The territorial trap: The geographical assumptions of international relations theory. Review of International Political Economy, 1 (1), 53-80.

AHMAD, M. I. (2002). Homeland insecurities: Racial violence the day after September 11. Social Text 72, 20 (3), 101-115.

AHMAD, M. I. (2004). A rage shared by law: Post-September 11 racial violence as crimes of passion. California Law Review, 92 (5), 1259-1330.

ALMAGUER, T. (1994). Racial fault lines: The historical origins of white supremacy in California. Berkeley, CA: University of California Press.

ANDRIJASEVIC, R. (2009). Sex on the move: Gender, subjectivity, and differential inclusion. Subjectivity, 29, 389-406.

BAKER, P. (2006, May 3). Administration is singing more than one tune on Spanish version of anthem. Washington Post. Retrieved from < http://www.washingtonpost. com/wp-dyn/content/article/2006/05/02/-AR2006050201594.html>.

BAKER-CRISTALES, B. (2009). Mediated resistance: The construction of neoliberal citizenship in the immigrant rights movement. Latino Studies, 7 (1), 60-82.

BAYOUMI, M. (2008). How does it feel to be a problem? Being young and Arab in America. New York, NY: Penguin.

BECK, U. (2000). What is globalization? Cambridge, UK: Polity Press.

BECK, U. (2002). The cosmopolitan society and its enemies. Theory, Culture \& Society, 19 (1-2), 17-44.

BECK, U.; SZNAIDER, N. (2006). Unpacking Cosmopolitanism for the Social Sciences: A Research Agenda. British Journal of Sociology, 57 (1), 1-23.

BERLANT, L.; FREEMAN, E. (1992). Queer nationality. Boundary 2, 19 (1), 149-180. BERUBE, A.; ESCOFFIER, J. (1991). Queer/nation. Out/Look: National Lesbian and Gay Quarterly, 11, 12-23.

BLOEMRAAD, I.; TROST, C. (2008). It's a family affair: Intergenerational mobilization in the spring 2006 protests. American Behavioral Scientist, 52 (4) 507-532.

BRENNER, N.; JESSOP, B.; JONES, M.; MacLeod, G. (2003). Introduction. In N. BRENNER, B. JESSOP, M. JONES; G. MACLEOD (eds.). State/space: A reader (p. 1-16). MALDEN, MA: Blackwell.

CAINKAR, L. (2002). No longer invisible: Arab and Muslim exclusion after September 
11. Middle East Report 224. Retrieved from <http://www.merip. org/mer/ mer224/224_cainkar.html>.

CAINKAR, L. (2003) Special registration: A fervor for Muslims. Journal of Islamic Law and Culture, 7 (2), 73-101.

CAINKAR, L. (2004). The impact of the September 11 attacks and their aftermath on Arab and Muslim communities in the United States. GSC Quarterly, 13. Retrieved from < http:// www.ssrc.org/programs/gsc/publications/quarterly13/cainkar.pdf >.

CAINKAR, L. (2005). Space and place in the metropolis: Arabs and Muslims seeking safety. City \& Society, 17 (2), 181-209.

CANTÚ, L. (2009). The sexuality of migration: Border crossings and Mexican immigrant men. N. A. NAPLES; S. VIDAL-ORTIZ, (Eds.). New York, NY: New York University Press.

CHACON, J. A. ; DAVIS, M. (2006). No one is illegal: Fighting racism and state violence on the U.S.-Mexico border. Chicago, IL: Haymarket Books.

CHAMBERS, S. A. (2009). A queer politics of the democratic miscount. borderlands e-journal, 8 (2). Retrieved from < http://www.border lands.net.au>.

CHERNILO, D. (2006). Social theory's methodological nationalism: Myth and reality. European Journal of Social Theory, 9 (1), 5-22.

CHERNILO, D. (2007). A social theory of the nation-state: The political forms of modernity beyond methodological nationalism. New York, NY: Routledge.

CHOCK, P. P. (1991). "Illegal aliens" and "opportunity": Myth-making in congressional testimony. American Ethnologist, 18 (2), 279-294.

CHON, M.; ARZT, D. E. (2005). Walking while Muslim. Law and Contemporary Problems, 68, 215-54.

CHOW, R. (2001). The secrets of ethnic abjection. In M. MORRIS; B. de BARY (eds.). "Race" panic and the memory of migration. (p. 53-78). Aberdeen and Hong Kong: Hong Kong University Press.

COLE, D. (2003). Enemy aliens: Double standards and constitutional freedoms in the war on terrorism. New York, NY: The New Press.

COUTIN, S. B. (1999). Citizenship and clandestinity among Salvadoran immigrants. POLAR: Political and Legal Anthropology Review, 22 (2), 53-63.

COUTIN, S. B. (2000). Legalizing moves: Salvadoran immigrants' struggle for U.S. residency. Ann Arbor, MI: University of Michigan Press.

COUTIN, S. B. (2003). Illegality, borderlands, and the space of nonexistence. In R. W. PERRY; B. MAURER (Eds.), Globalization under construction: Governmentality, law, and identity (p. 171-202). Minneapolis, MN: University of Minnesota Press.

CRAWFORD, C. (2007). "Aquí estamos y no nos vamos!": Justice for janitors in Los Angeles and new citizenship claims. In D. SEGURA; P. ZAVELLA (eds.). Women and migration in the U.S.-Mexico borderlands: A reader (p. 306-324). Durham, NC: Duke University Press.

ÇUBUKÇU, A. (2008). Humanity must be defended? Unpublished Ph.D. dissertation, Department of Anthropology, Columbia University (New York).

DAULATZAI, S. (2007). Protect ya neck: Muslims and the carceral imagination in the 
age of Guantánamo. Souls, 9 (2), 132-147.

DE GENOVA, N. (1998). Race, space, and the reinvention of Latin America in Mexican Chicago. Latin American Perspectives, 25 (5), 91-120.

DE GENOVA, N. (2002). Migrant "illegality" and deportability in everyday life. Annual Review of Anthropology, 31, 419-47.

DE GENOVA, N. (2005). Working the boundaries: Race, space, and 'illegality' in Mexican Chicago. Durham, NC: Duke University Press.

DE GENOVA, N. (2007a). The production of culprits: From deportability to detainability in the aftermath of "Homeland Security." Citizenship Studies, 11 ( 5), 421-48.

DE GENOVA, N. (2007b). The stakes of an anthropology of the United States (2007). CR: The New Centennial Review, 7 (2), 231-77.

DE GENOVA, N. (2008). "American" abjection: "Chicanos," gangs, and Mexican/migrant transnationality in Chicago. Aztlán: A Journal of Chicano Studies, 33 (2), 141-74.

DE GENOVA, N. (2009). Conflicts of mobility, and the mobility of conflict: Rightlessness, presence, subjectivity, freedom. Subjectivity, 29, 445-466.

DE GENOVA, N. (2010a). Alien Powers: Deportable Labour and the Spectacle of Security. In V. SQUIRE (ed.). The contested politics of mobility: Borderzones and irregularity. London: Routledge.

DE GENOVA, N. (2010b). The Deportation Regime: Sovereignty, Space, and the Freedom of Movement. Theoretical Overview. In N. DE GENOVA; N. PEUTZ (eds.). The deportation regime: Sovereignty, space, and the freedom of movement (p. 33-65). Durham, NC: Duke University Press.

DE GENOVA, N.; Ramos-Zayas, A. Y. (2003). Latino crossings: Mexicans, Puerto Ricans, and the politics of race and citizenship. New York: Routledge.

DUGGAN, L. (1994). Queering the State. Social Text, 39, 1-14.

FERNANDES, D. (2007). Targeted: Homeland security and the business of immigration. New York, NY: Seven Stories Press.

FERNÁNDEZ, C. (1991). Undocumented aliens in the queer nation. Out/Look: National Lesbian and Gay Quarterly, 11, 15-19.

GAMSON, J. (1995). Must identity movements self-destruct? A queer dilemma. Social Problems, 42 (3), 390-407.

GIDDENS, A. (1973). The class structure of the advanced societies. London: Hutchinson. GIDDENS, A. (1985). The nation-state and violence. Cambridge, UK: Polity Press.

GONZALES, A. (2009). The 2006 mega marchas in Greater Los Angeles: Counterhegemonic moment and the future of el migrante struggle. Latino Studies, 7 (1), 30-59.

GORDON, J.; LENHARDT, R. A. (2006). Citizenship talk: Bridging the gap between immigration and race perspectives. Fordham Law Review, 75, 2493-2520.

HALPERIN, D. M. (1995). Saint Foucault: Towards a gay hagiography. NewYork, NY: Oxford University Press.

HEISKANEN, B. (2009, December 1). A day without immigrants. European Journal of American Studies, Special issue: 2009, document 3. Retrieved from < http://ejas. revues.org/document7717.html $>$. 
HINCAPIÉ, M. (2009). Aqui estamos y no nos vamos: Unintended consequences of current U.S. immigration law. In F. ANSLEY; J. SHEFNER (eds.). Global connections, local receptions: new latino immigration to the southeastern United States (p. 89128). Knoxville, TN: University of Tennessee Press.

HINDESS, B. (2000). Citizenship in the international management of populations. American Behavioral Scientist, 43 (9), 1486-97.

HOLLOWAY, J. (1994). Global capital and the national state. Capital and Class, 52, 23-49.

HONIG, B. (1998). Immigrant America? How foreignness "solves" democracy's problems. Social Text, 56, 1-27.

HONIG, B. (2001). Democracy and the foreigner. Princeton: Princeton University Press.

HUMAN RIGHTS WATCH. (2002). Presumption of guilt: Human rights abuses of post-September 11 detainees. Retrieved from < http:// www.hrw.org/reports/2002/ us911>.

JOHNSON, K. R.; ONG HING, B. (2007). The immigrant rights marches of 2006 and the prospects for a new civil rights movement. Harvard Civil Rights -Civil Liberties Law Review, 42, 99-138.

ISIN, E. F. (2008). Theorizing acts of citizenship. In E. F. ISIN; G. M. NIELSEN (eds.). Acts of Citizenship (p. 15-43). London: Zed Books.

ISIN, E. F. (2009). Citizenship in flux: The figure of the activist citizen. Subjectivity, 29, 367-388.

KARAKAYALI, S.; RIGO, E. (2010) Mapping the European space of circulation. In N. DE GENOVA; N. PEUTZ (eds.). The deportation regime: Sovereignty, space, and the freedom of movement (p. 123-144). Durham, NC: Duke University Press.

KRISTEVA, J. (1982). Powers of horror: An essay on abjection (Leon S. Roudiez, Trans.). New York, NY: Columbia University Press. (Original work published 1980)

LAZOS VARGAS, S. R. (2007). The immigrant rights marches (las marchas): Did the gigante (giant) wake up or does it still sleep tonight? Nevada Law Journal, 7, 780-825.

LIPSITZ, G. (2006). "Home is where the hatred is": Work, music, and the transnational economy. In A. CHABRAM-DERNERSESIAN (ed.). Chicana Cultural Studies Reader (p. 299-313). New York, NY: Routledge.

LUIBHÉID, E. (2002). Entry denied: Controlling sexuality at the border. Minneapolis, MN: University of Minnesota Press.

LUIBHÉID, E. (2008). Sexuality, migration, and the shifting line between legal and illegal status. GLQ: A Journal of Lesbian and Gay Studies, 14 (2-3), 289-315.

LUIBHÉID, E.; CANTÚ, L. (eds.). (2005). Queer migrations: Sexuality, U.S. citizenship, and border crossings. Minneapolis, MN: University of Minnesota Press.

MAIRA, S. (2004). Youth culture, citizenship and globalization: South Asian youth in the United States after September 11th. Comparative Studies of South Asia, Africa, and the Middle East, 24 (1), 219-31.

MAIRA, S. (2009). Missing: Youth, citizenship, and empire after 9/11. Durham, NC: Duke University Press.

MAIRA, S. (2010). Radical deportation: Alien tales from Lodi and San Francisco. In N. 
DE GENOVA; N. PEUTZ (eds.). The deportation regime: Sovereignty, space, and the freedom of movement (p. 295-325). Durham, NC: Duke University Press.

MARTINS, H. (1974). Time and theory in sociology. In J. REX (ed.). Approaches to sociology (p. 246-294). London: Routledge \& Kegan Paul.

MARX, K. (1976). Capital: A critique of political economy. Volume One. (Ben Fowkes, Trans.). New York, NY: Penguin Books (Original work published 1867).

MCNEVIN, A. (2006). Political belonging in a neoliberal era: The struggle of the sanspapiers. Citizenship Studies, 10 (2): 135-51.

MCNEVIN, A. (2009). Doing what citizens do: Migrant struggles at the edges of political belonging. Local-Global: Identity, Security, Community, 6, 67-77.

MEZZADRA, S. (2001). Diritto di fuga: Migrazioni, cittadinanza, globalizzazione. Verona, Italy: Ombre corte.

MEZZADRA, S. (2004). The right to escape. Ephemera, 4 (3): 267-275. Retrieved from <http://www.ephemeraweb.org/journal/4-3/4-3mezzadra.pdf >.

MEZZADRA, S. (2006). Citizen and subject: A postcolonial constitution for the European Union? Situations, 1 (2), 31-42.

MEZZADRA, S. (2010). Capitalism, migration, and social struggles: Towards a theory of the autonomy of migration. In VICKI SQUIRE (ed.). The contested politics of mobility: Borderzones and irregularity. London: Routledge.

MEZZADRA, S.; NEILSON, B. (2003). Né qui, né altrove - Migration, detention, desertion: A dialogue. Borderlands e-journal, 2 (1). Retrieved from < http://www. borderlandsejournal.adelaide.edu.au/vol2no1_2003/mezzadra_neilson.html $>$.

MONTGOMERY, D. (2006, April 28). An anthem's discordant notes: Spanish version of "Star-Spangled Banner" draws strong reactions. Washington Post. Retrieved from <http://www.washingtonpost.com/wp-dyn/content/article/2006/04/27/ AR2006042702505.html>.

MOULIER BOUTANG, Y. (1998). De l'esclavage au salariat. Economie historique du salariat bridé. Paris: Presses Universitaires de France.

MOULIER BOUTANG, Y. (2001). Between the hatred of all walls and the walls of hate: The minoritarian diagonal of mobility. In M. MORRIS; B. de BARY (eds.). "Race" panic and the memory of migration (p. 105-30). Aberdeen and Hong Kong: Hong Kong University Press.

MOULIER BOUTANG, Y.; GARSON, J-P. (1984). Major obstacles to control of irregular migrations: Prerequisites to policy. International Migration Review, 18 (3), 579-592.

NYERS, P. (2003). Abject cosmopolitanism: The politics of protection in the antideportation movement. Third World Quarterly, 24 (6), 1069-93.

PAPADOPOULOS, D.; STEPHENSON, N.; TSIANOS, V. (2008). Escape routes: Control and subversion in the 21st Century. London: Pluto Press.

PEUTZ, N. (2007). Out-laws: Deportees, desire, and "the law." International Migration, 455 (3), 182-191.

PHILLIPS, C. (2009). Difference, disagreement and the thinking of queerness. borderlands e-journal, 8 (2). Retrieved from < http://www.border lands.net.au>. 
PUAR, J. K. (2007) Terrorist assemblages: Homonationalism in queer times. Durham, NC: Duke University Press.

PUAR, J. K.; RAI, A. S. (2002). Monster, terrorist, fag: The war on terrorism and the production of docile patriots. Social Text 72, 20 (3), 117-48.

PULIDO, L. (2007). A day without immigrants: The racial and class politics of immigrant exclusion. Antipode, 39 (1), 1-7.

RANCIÈRE, J. (1995). On the shores of politics (L. Heron, Trans.). New York, NY: Verso (Original work published 1992).

RANCIÈRE, J. (1999). Dis-agreement: Politics and philosophy. Minneapolis, MN: University of Minnesota Press (Original work published 1995).

RANCIÈRE, J. (2004). Who is the subject of the rights of man? South Atlantic Quarterly, $103(2 / 3), 297-310$.

RANCIÈRE, J. (2006). Democracy, republic, representation. Constellations, 13 (3), 297-307.

ROBINSON, W. I. (2006). "Aquí estamos y no nos vamos!" Global capital and immigrant rights. Race \& Class, 48 ( 2), 77-91.

ROEDIGER, D. R. (1991). The wages of whiteness: Race and the making of the American working class. New York, NY: Verso.

SAITO, N. T. (2001). Symbolism under siege: Japanese American redress and the "racing" of Arab Americans as "terrorists". Asian Law Journal, 8, 1-29.

SCHINKEL, W. (2010, January). Culturalism and the sociology of "integration." Paper presented at the conference "The language of difference: Mechanisms of inclusion and exclusion of migrants, 1945-2005," sponsored by the Department of History, University of Leiden, Netherlands.

SOMERVILLE, S. B. (2002). Introduction: Queer fictions of race. MFS: Modern Fiction Studies, 48 (4), 787-794.

SOMERVILLE, S. B. (2005). Sexual aliens and the racialized state: A queer reading of the 1952 U.S. Immigration and Nationality Act. In E. LUIBHÉID; L. CANTÚ (eds.). Queer migrations: Sexuality, U.S. citizenship, and border crossings (p. 75-90). Minneapolis: University of Minnesota Press.

STOLER, A. L. (2006). On degrees of imperial sovereignty. Public Culture, 18 (1): 125-146.

TAKAKI, R. (1979). Iron cages: Race and culture in 19th-century America. New York, NY: Oxford University Press.

VARSANYI, M. W. (2006). Interrogating "urban citizenship" vis-à-vis undocumented migration. Citizenship Studies, 10 (2): 229-249.

VILLA, R. H. (2000). Barrio-logos: Space and place in urban Chicano literature and culture. Austin, TX: University of Texas Press.

VOLPP, L. (2002). The citizen and the terrorist. UCLA Law Review, 49, 1575-1598.

WIMMER, A.; GLICK SCHILLER, N. (2003). Methodological nationalism, the social sciences, and the study of migration: An essay in historical epistemology. International Migration Review, 37 (3), 576-610. 


\section{Abstract}

\section{The Queer Politics of Migration: Reflections on "Illegality" and Incorrigibility}

The most resounding expression of the truly unprecedented mobilizations of migrants throughout the United States in 2006 was a mass proclamation of collective defiance: iAquí Estamos, y No Nos Vamos! [Here we are, and we're not leaving!!. This same slogan was commonly accompanied by a still more forcefully incorrigible rejoinder: iY Si Nos Sacan, Nos Regresamos! [... and if they throw us out, we'll come right back!]. It is quite striking and, as this essay contends, not merely provocative but genuinely productive to note the affinity between the crucial articulation of this radically openended politics of migrant presence with the similarly abject and profoundly destabilizing politics of queer presence. In a manner remarkably analogous to the slogan, "We're here, we're queer, get used to it!", the dynamic enunciation of these phrases in the context of the mass mobilizations of migrants asserted an irreducible spirit of irreverence and disaffection for state power. Both gestures unreservedly and unapologetically assert not only their irreversible presence, furthermore, but also uphold the intractable challenge of their own intrinsic incorrigibility.

Keywords: undocumented migration, war on terrorism, deportation/ deportability, politics of mobility, politics of presence.

Recebido para publicação em 01/08/2015

Aceito para publicação em 22/10/2015

Received for publication in August, 015t, 2015

Accepted for publication in October, 22 ${ }^{\text {th }}, 2015$

ISSN impresso 1980-8585

ISSN eletrônico 2237-9843

http://dx.doi.org/10.1590/1980-85852503880004503 